https://doi.org/10.18485/iipe_euchanges.2021.ch23

\title{
THE CO-OPERATION BETWEEN THE EUROPEAN UNION AND LATIN AMERICAN COUNTRIES
}

\begin{abstract}
Ivan DUJIĆ ${ }^{1}$
Abstract: The main aim of this paper is to present the historical development of economic and political relations between the European Union (EU) and Latin American countries. The emphasis is put on the following research question: To what degree has the economic and political co-operation between the EU and Latin American countries been developed? The author points to the key facts and events that gradually influenced the co-operation to their full extent, despite some inequalities between these regions. In addition, the author highlights the Fourth Industrial Revolution that underpins contemporary relations and its impact on the development of both EU and Latin American countries, as well as its effects on mutual relations. The paper concludes that thanks to bi-regional cooperation, the countries of these parts of the world are capable to define a common language in the field of economic and political relations in the Fourth Industrial Revolution.
\end{abstract}

Keywords: EU, Latin America, bi-regional cooperation, contemporary relations, the Fourth Industrial Revolution

\section{INTRODUCTION}

Latin American countries have been trying for decades to improve their global political and economic situation in the global arena. From time to time, they were quite successful in that, but there were also times when those

\footnotetext{
${ }^{1}$ Research Fellow at the Institute of International Politics and Economics, Belgrade, Serbia. E-mail: ivan@diplomacy.bg.ac.rs

The paper presents findings of a study developed as a part of the research project "Serbia and challenges in international relations in 2021", financed by the Ministry of Education, Science, and Technological Development of the Republic of Serbia, and conducted by the Institute of International Politics and Economics, Belgrade.
} 
countries were not satisfied with economic and political reforms. Political turmoil, several economic crises, poor relations between neighbouring countries, corruption and the production of illicit drugs are some of the main problems in Latin America. However, Latin American countries tend to shape a different future, trying to change the economic and political landscape. Among many things that they want to alter is their relations with the EU. To this end, several things need to change.

It is the reason why this paper is dealing with two topics in that regard. The first topic is dedicated to the historical development of political and economic relations between Latin American countries and the EU. The second part of the paper will compare the effects of the Fourth Industrial Revolution on both entities, as well as on their bilateral relations.

For the first part of the paper historical method along with descriptive statistical analysis is used and for the second part, comparative and case study analysis. This kind of methodology will help to explain major analytical points and the conclusion of this paper.

\section{THE DEVELOPMENT OF POLITICAL AND ECONOMIC RELATIONS BETWEEN THE EU AND LATIN AMERICA}

Complex economic and political relations between the EU and Latin American countries began developing during the Cold War when the European Communities existed as the sole actors in international relations, tasked with representing an integrated sub-region comprising European countries among other actors of international relations. Portugal and Spain acceding to the European Communities was a significant incentive for the future EU to establish bi-regional relations with Latin American countries (Gardini\&Ayuso, 2015, p. 10). These relations have not always been deepened, nor have Latin American countries been a standing priority for EU foreign policy.

As Freres noted at the end of the $20^{\text {th }}$ century, the EU treated Latin American countries differently during the Cold War and immediately after it, which can be seen in the changes in the sphere of foreign trade of the EU and Latin American countries. In the post-Cold War period, the EU had a positive attitude towards Latin American countries: foreign trade between these parts of the world increased by 50\% between 1991 and 1997 (Freres, 2000, p. 70).

The beginning and the first decade of the $21^{\text {st }}$ century were marked by notable steps taken towards increased economic and political co-operation 
between the EU and Latin American countries. The continued integration processes between the countries of Central and South America, including the Caribbean countries, have encouraged the EU to improve economic and political co-operation with these countries. Dujić points to the importance of the co-operation between the EU and Central American countries during the first decade of the $21^{\text {st }}$ century favouring greater EU influence on this part of Latin America, as well as on the integration processes (Dujić, 2007, p. 89).

The argument in favour of the EU's efforts to keep economic and political influence not only in Central American but also in other Latin American countries rests on its continued support for the difficult and often slow integration processes between Latin America and the Caribbean that have been taking place since 2015 (European Parliament, 2020, p. 15). From a (geo)political point of view, using its economic and political influence, the EU tacitly seeks to gradually suppress the United States (US) by occasional efforts to influence Latin American countries. This tendency is perceived by numerous scholars, including Dujić, who indicates the EU had economic and political goals related to the integration processes between the Central American countries, set forth in the Regional Strategy Paper (Dujić, 2007, p. 89).

Apart from supporting the integration processes between the countries of Central and, more broadly, Latin America, the EU establishes political cooperation with these countries through, for example, holding bi-regional summits. During the second decade of this century, the EU held two such summits with Latin American countries - in Santiago de Chile and Brussels in 2013 and 2015, respectively (European Sources Online - ESO, 2016, pp. 13-14). Although no summits have been held between the EU and Latin American countries since 2015, the goal of bringing together heads of states or their governments, as well as foreign ministers, is to discuss current issues concerning EU-Latin America relations, including issues of continued integration processes between these countries, with the aim of affirming the significant political influence of the EU in Latin America (European Parliament, 2020, p. 20).

Can the EU's political influence on Latin American countries be exerted independently of economic influence to encourage long-term political cooperation? Political co-operation cannot take place separately from the economic influence and established economic co-operation. Thus, international trade was established between the EU and Latin American countries to include all goods in international trade in goods (Schejtman, 2004, pp. 66-67). 
According to the latest data, the percentage of trade between the EU and Latin American countries was uneven relative to US's and China's foreign trade with these countries: the EU reached the highest percentage of foreign trade with members of the Southern Common Market (Mercado Común del Sur - MERCOSUR) $-20.1 \%$, trading in machinery and transport equipment, food and live animals, chemicals, crude materials, manufactured goods and other products (European Parliamentary Research Service (EPRS), 2019, p. 20). In addition to these items, mutual trade includes trade in computers, supported by the 1996 Information Technology Agreement (World Trade Organization - WTO, 2020, p. 134), the use of which, as seen in the United States and Western Europe, enables further development of the Fourth Industrial Revolution (Haskel \& Westlake, 2018, pp. 81-82).

The question of whether Latin American countries can be the equal of the EU in leading the Fourth Industrial Revolution is answered by data indicating significant progress of some Latin American countries in this regard. The potential of Latin American countries to overcome their lagging behind the EU is evidenced by the cases of Brazil, Chile and Mexico, where there is a notable increase in the percentage of the use of the Internet in digital connectivity, which is the key to the Fourth Industrial Revolution in the business world. The examples of these countries show that the Internet is $100 \%$ used by large companies, mostly for receiving and sending e-mails, then for searching data related to goods and services, while e-banking ranks third (The Economic Commission for Latin America and the Caribbean ECLAC, 2018, p. 69)

While one would expect to discuss how many companies, including multinational companies, originating from the EU operate in Latin American countries, the focus is on Latin American-based companies operating in the EU. Before the 2008 global financial crisis erupted, some companies from Brazil and Mexico had noticeably developed their business not only in the New World, comprising Latin American countries but also in the EU. For example, one Mexican company, the Alfa conglomerate, had developed partnerships and strategic alliances both in the US and Europe (OECD, 2007, p. 17).

Since in the post-global financial crisis period Latin American companies encountered administrative and other obstacles to do business in the EU, statistics indicate that only a fifth of SME exports from Latin American countries goes to the EU market, of which a fifth to Spain (EU-LAC Foundation, CERALE \& Institut des Amériques, 2017, p. 45). This means that the Latin American companies' trade with the EU puts the EU in a 
weaker position compared to the US and that its better positioning in the global market requires strong and frequent bi-regional co-operation between the EU and Latin American countries.

The Graph shows that the 2013-2016 period saw a gradual decline in EU FDI flows in Latin American countries. During that period, despite the migrant crisis that hit the whole of Europe in 2015, the EU did not significantly reduce investments in Latin America. This period was followed by a period of accelerated decline in FDI in Latin American countries during 2016. The sharp decline of FDI in Latin American countries was the result of a gradual deepening of the crisis of the integration processes in Latin America. Finally, the last period given in this graph - covering 2017 and 2018 - shows a very low level of EU investment in Latin American countries. Despite the EU's commitment to continuous co-operation with Latin American countries, in this period, there was a change in the EU's foreign policy towards these countries as the EU primarily attended to their own business.
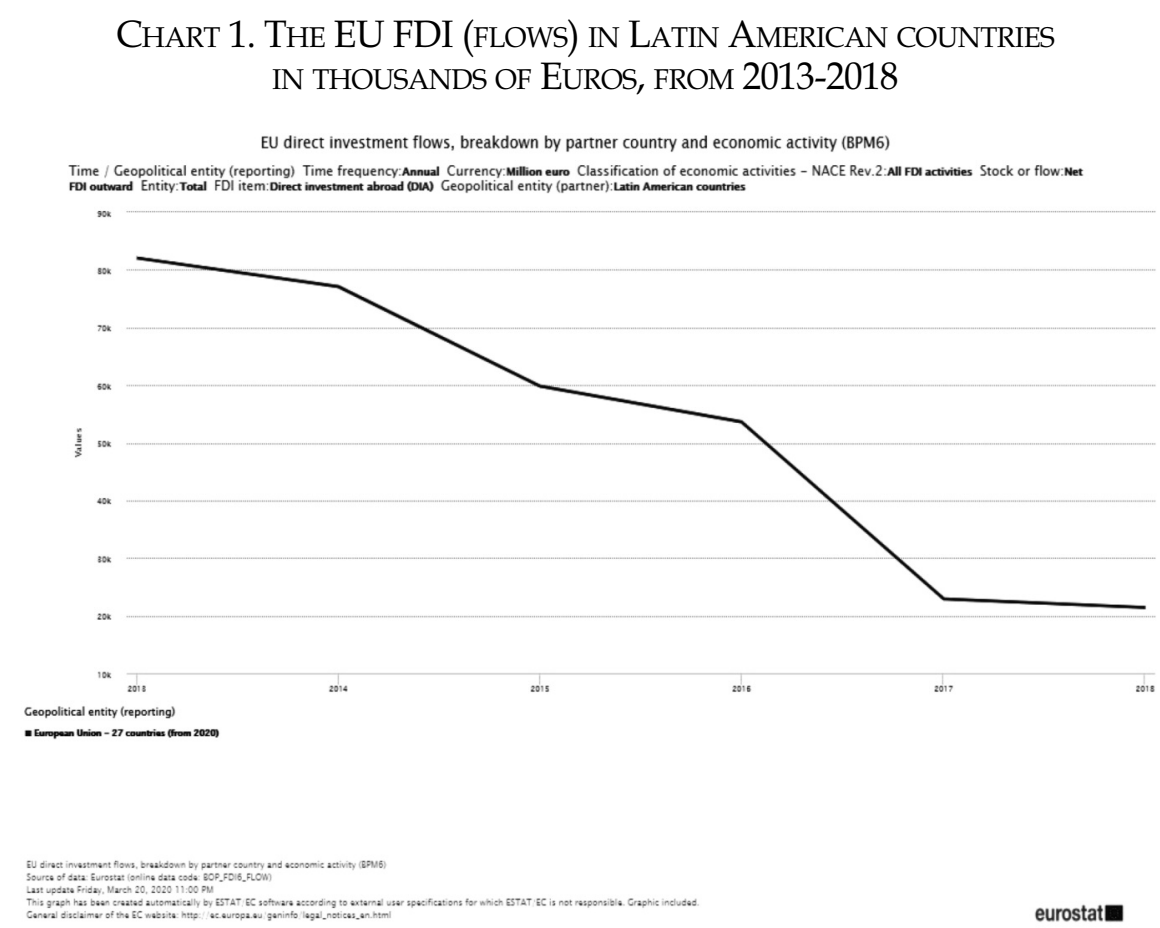

Source: Eurostat database 


\section{CO-OPERATION BETWEEN THE EU AND LATIN AMERICAN COUNTRIES SPURRED BY THE FOURTH INDUSTRIAL REVOLUTION}

In the digital age, communication technologies are leading to a state in which the material world has become completely overcome. This is one of the essential features of the Fourth Industrial Revolution. Throughout the period preceding a sizeable decline of EU FDI inflows to Latin American countries until 2019, a fully-fledged co-operation was developed between these regions in the field of economic and political relations. Nowadays, in the digital age, co-operation stems from the fact that it is spurred by communication technologies and the Fourth Industrial Revolution.

Communication technologies and the Fourth Industrial Revolution are based on digitisation. This is indicated by Wajcman, cited by Flecker in his research, who perceives digitisation as ' $[$...] the acceleration of production and communication [...]' (Flecker, 2018, p. 365). The environment of instant communication further encourages 'the process of disintegration of national production and integration of international trade' (Feenstra, 1998), which has a positive effect on connecting physically remote capital and remote locations, as is the case with the EU and Latin American countries.

The EU and Latin American countries nurture multiple forms of cooperation that reflect not only the effort to preserve established ties and global discourse on the most vital issues in the field of the global economy and politics but also certain steps towards defining capitalism. Immediately after the Cold War and at the height of the Third Industrial Revolution, when capitalism seemed to have a tendency to remain as an exclusive global phenomenon, the major capitalist states of Europe exerted their effort to advance information technologies (Wilkinson, 1993, p. 33) that can be upgraded with digital technologies. Moreover, since the end of the Cold War, the aforementioned countries and the US have worked rapidly to develop the Fourth Industrial Revolution. It was a great challenge for Latin American countries to adapt the complex reality of technological changes as a consequence of introducing digital technologies.

After the Cold War era, it seemed that accelerated progress of digital technologies would not be achieved in Latin American countries, nor that evaluation of companies' and corporations' intangible assets (intangible economy) would prevail. On the contrary, instead of an economy becoming highly dependent on companies' and corporations' tangible assets, the modern economy in Latin America implies 'knowledge-based assets' 
(O'Reilly, Ranft \& Neufeind, 2018, p. 3). Unlike the previous three industrial revolutions which were characterised by economy depending on the revenue from selling finished goods, the Fourth Industrial Revolution is featured by a new economy in which the emphasis has not been put on finished goods, but on the evaluation of projects, as well as the means of communication between people by using national statistics (Haskel \& Westlake, 2018, pp. 55).

The fundamental difference between the Fourth Industrial Revolution and the previous revolutions can be observed by the need to connect knowledge - which is an intangible thing - with forms of communication between people, for the sake of its evaluation not only in favour of finished goods but also a wider networking of individuals and companies. In this sense, Haskel and Westlake note that the Fourth Industrial Revolution has been unfolding towards a phase that inevitably leads to increased ' $[. .$. importance of communications and connections between people and between businesses, and (...) infrastructure [...]' (Haskel \& Westlake, 2018, p. 152). Until the eruption of the global financial crisis in 2008 and the outbreak of the coronavirus in 2020, the EU and Latin American countries sought to continuously improve communication and connections between people and companies through mutual co-operation, with the aim of connecting local spaces not only within countries but also among them.

The assumption that an intangible economy represents an integral part of the commitment and persistent effort to connect local spaces in favour of achieving territorial unity of a state, as well as connecting spaces within several states, raises the question of whether this is feasible in the absence of capital. It can be said that it is feasible, considering that capital - which has been tied to tangible assets for centuries - has been denied and transformed into intangible capital. Recent research indicates that intangible capital is

'[...] coherent with national accounting practices (that) is essential for a deeper understanding of the sources of growth and for the design of macroeconomic policies aimed at stimulating sustained growth, competitiveness and sustainable development' (Corrado, Haskel, JonaLasinio \& Iommi, 2016, p. 2).

Intangible capital provides an incentive for macroeconomic policies that, in the case of Latin American countries, strive to stimulate economic growth and aim to reduce economic and political backwardness vis-à-vis the EU. A deeper analysis of the causes that have led to backwardness in the development of Latin American countries shows that this part of the world 
has failed to create tangible capital. According to De Soto, backwardness does not refer to the level of education and culture evident in Latin American countries, but to their inability to create 'much live capital' (De Soto, 2000, p. 170).

One of the possible reasons living capital was not created or globally expanded throughout Latin American countries might be the suspension of loans, for example, by Germany (Kindleberger, 1996, p. 158). As regards the global capital of Latin American countries, it is noticed that it is frequently 'more dependent on the territorial state than any imperial power has ever been before' (Wood, 2005, p. 15). Therefore, we can say that Latin American countries faced difficulties in developing both living and global capital that would confirm educational and cultural values of the economically active population - in favour of both a better status of Latin American countries in the global expansion of capital and greater equality with respect to the EU in the Fourth Industrial Revolution.

Another possible reason why there was no creation and expansion of living capital in Latin American countries refers to the constitution of Spain, which, as a colonial power, was once depended on Latin American countries. While Portugal and other colonial powers created capital, both in their colonies and own territories, Spain existed as a regressive absolute monarchy. Due to this status, Spain lost most of its colonies in Latin America as early as the beginning of the $19^{\text {th }}$ century, so it is not surprising that ' $[. .$. Spain was never able to assert genuine supremacy, either in Western Europe itself or across the oceans' (Brzezinski, 1997, p. 19).

An additional argument that Spain was a regressive monarchy refers to the slow accumulation of physical capital which was provided by former colonies. In their findings, Molinas and Escosura note that '[...] Spanish accumulation (of physical capital) did not converge to the European norm. Physical capital formation started (...) at a very low level [...]' (Molinas \& Escoura, 1989, pp. 393-394). Material capital, manifested in the form of physical capital, developed slowly in Spain due to the lack of a developed liberal democracy and the possible risk of falling into a dictatorship. This is also highlighted by Drake when he indicates that in Spain and some Latin American countries 'before the dawn of the dictatorships, working-class militancy had fled to frighten property owners, who therefore abandoned liberal democracy' (Acemoglu \& Robinson, 2006, p. 72).

The reality has shown that inequality between the EU and Latin American countries is a serious obstacle in the Fourth Industrial Revolution to work on providing a general, common definition of capitalism, as Latin 
American countries have given a different response to its development. Some Latin American countries, such as Bolivia, Cuba, and Venezuela, have had a strong vision to abandon capitalism as an economic system but they exactly save it in the existing form. For the time being, only Cuba, with its one-party political system, has managed to completely replace capitalism with another economic system - socialism ' [...] as (the) state-centric (system) [...]' (Hernández, 2015, p. 167).

Unlike Cuba, Bolivia and Venezuela did not introduce socialism as a one-party state-centric system after the failure of right-wing politics. The case of Venezuela shows that proclaimed 'socialism of the $21^{\text {st }}$ century' was an attempt to overcome political instability as ' $[$...] political institutions have remained weak and unstable [...]' (Panizza, 2009, p. 185). Factors that, in addition to inequality, make it impossible to define capitalism more broadly, are weak and unstable political institutions responsible for creating a discourse in favour of understanding capitalism as a non-economic, social concept.

Since its independence and until the end of the Second World War, Venezuela has suffered severely from a lack of stable political institutions. Rómulo Betancourt was responsible for the success in maintaining stable institutions in this country over the long run, and with his great influence in the realm of public policy, he significantly reduced the threat of dictatorships. According to Magstadt, unlike his predecessors, Betancourt fought hard against dictatorship until he was elected as President of Venezuela, and he continued doing that during his presidency. His successful reign may be explained by the fact that he ruled much longer than his predecessors. Namely, '[...] no democratic ruler had survived in office for even 2 years' (Magstadt, 2013, p. 311). The suppression of dictatorship provided a genuine opportunity for a broader understanding of capitalism, since no ideas had been developed, no initiatives launched, nor programmes designed during the periods of dictatorships in favour of providing goods in the realm of public policy.

The extent to which Betancourt has succeeded in advancing Venezuelan political culture, insofar as to oppose dictatorship - a relapse from the past - is supported by Mainwaring's findings which point to the erosion of democracy after Betancourt's resignation from the office. In fact, Mainwaring points to the deep crisis of representation in Venezuela during the 1990s, which was often the result of a deeper and '[...] growing disenchantment with the existing political system' (Mainwaring, 2006, p. 14). The period of unexpected erosion of democracy in Venezuela and other 
Latin American countries with a weak political culture, was accompanied by the upsurge of moderate and radical left-wing political streams and even marginal political parties. The military had a mediating role in the aforementioned, i.e., it lost its significance. Namely, within the periods characterised by dictatorships, the military played a dominant role in making economic and political decisions and, according to Kruijt, it was crucial in a new definition of capitalism (Kruijt, 2001, p. 411).

Whilst there are more possibilities for Cuba and Venezuela to continue to be part of global information infrastructure, despite their weak political culture, Bolivia has been for decades seriously faced with the perennial problem - how to overcome its backwardness and reduce the poverty rate (Dujić, 2016, p. 52). The close correlation between global information infrastructure and digital technologies is evidenced by the fact that, for instance, South American countries as part of Latin America committed themselves under the leftist government to co-operate in further technological development with the aim of carrying out the sub-regional integration process (Union of South American Nations - UNASUR, Article 3, n).

On the other hand, the Left in the EU, particularly in the United Kingdom during the second half of the last decade of the twentieth century, did not deal with the issue of defining capitalism. Instead of it, at the time of the moderate left-wing's rise in Latin America and the empowerment of the EU, there was a greater demand to assume '[...] the normative ideal of liberal democratic political discourse' (McNair, 1999, p. 115). The need to establish and sustain a discourse on strong and stable political institutions, thanks to the normative ideal of liberal democratic political discourse, was founded on the EU's and politically stable Latin American countries' preparations for the Fourth Industrial Revolution and the provision of opportunities for a broader non-economic definition of capitalism.

Does the Fourth Industrial Revolution encourage the development of a new form of capitalism, which, in addition to the EU, is also taking place in Latin American countries? Frank, quoted by Smith, notes that maintaining multiple ties in the form of Latin American dependence on Spain and Portugal, as mother countries and former metropolises, has contributed over the long run to the gradual involvement of Latin American countries into the Fourth Industrial Revolution, as they

'[...] become integrated into hierarchies of core-periphery relations (that) are not backward in the sense of having pre-capitalist relations of production. Rather, they become part of the capitalist system and in the case of Latin America had been since the sixteenth century when the 
mercantilist economies of Spain and Portugal had implanted the seeds of capitalism' (Smith, 2003, p. 90).

In order to become part of the capitalist system, Latin American countries endeavoured to re-formulate capitalism by pursuing their social policies. Since gaining independence, Latin American countries have committed themselves to work on the further development of social policies. This is one of the goals of the document known as 'Millennium Development Goals', which states that by 2020 the living conditions of at least 100 million slum dwellers should be improved. The success of Latin American countries in gradually improving the living conditions of the population in slums was recorded when the percentage of such residents was reduced from 29 to 20 percent (United Nations, 2015, p. 60). Such success is also vital for defining capitalism in the EU and Latin American countries.

The achieved objectives set forth in the Millennium Development Goals resulted in the adoption of a new document: 'Sustainable Development Goals'. Based on this document, the EU and Latin American countries have achieved the key objectives of development, such as a significant increase in the percentage of children with completed primary education (the World Bank Group and the United Nations Development Programme, 2016, p. 69).

Have the Millennium Development Goals promoted political, economic, and social progress in Latin American countries vis-à-vis the EU? Drawing on the great significance of the Fourth Industrial Revolution, it is possible to achieve progress in the economy and politics, as well as in the sphere of social policy, and comply these policies with the millennium and sustainable development goals. If the appropriate level of human development is achieved, there will be enough room for a broader definition of capitalism as a non-economic system. However, statistics according to the Human Development Report show that among Latin American countries, only Chile and Argentina have achieved a very high level of human development, being ranked $43^{\text {rd }}$ and $46^{\text {th }}$ respectively (UNDP, 2020, p. 347).

Even though, according to many benchmarks, a balanced level of human development has not been achieved in Latin American countries, the EU has developed close co-operation with these countries until 2019 and the outbreak of the coronavirus. Numerous issues, including technological development, are the subject of long-term cooperation between the EU and Latin American countries. The scope of the EU's activity to co-operate with Latin American countries at the beginning of the $21^{\text {st }}$ century in the field of technological development is reflected in the fact that its foreign policy was, 
among other things, directed towards the support of small and medium enterprises (the European Parliament, 2012, pp. 34-35).

\section{CONCLUSION}

In the age of the Fourth Industrial Revolution, as well as general interdependence, the EU and Latin American countries are facing the challenge of how to nurture and strengthen mutual co-operation. Although the past economic and political co-operation seems to have weakened under the influence of the pandemic, the European Union and Latin American countries have paved the way for developing and advancing a new form of interdependence - digital interdependence based on information technologies and the Fourth Industrial Revolution. Co-operation between the EU and Latin American countries has reached a stage when its results should be maintained thanks to the Fourth Industrial Revolution.

Given the inequality between the EU and Latin American countries in terms of the level of human development and democracy development, the EU's bi-regional economic and political relations with Latin American countries are likely to continue. Under the influence of information technologies and the Fourth Industrial Revolution, both regions are determined to address issues such as combating corruption, solving migration crisis and mitigating the negative effects of climate change (European Parliament, 2020, p. 28). Continued and deepened co-operation between the EU and Latin American countries during the Fourth Industrial Revolution may lead to an increase in the level of human development in Latin American countries, provided that efforts are made to improve the level of democracy development.

According to Freres and other scholars, the importance of the EU in advancing the development of democracy in Latin American countries is seen in the fact that it offers itself as a role model for other blocs (Malamud, 2010, p. 647). For Latin American countries, this means that they will be able to rely on political co-operation with the EU to defend fragile democracy in their overall development. Instead of continuing to suffer from weak democracy, Latin American countries have a great chance to strengthen it so that they can truly take advantage of the many benefits of the Fourth Industrial Revolution.

The benefits of the Fourth Industrial Revolution are evidenced, for example, by the positive attitude of the United Nations, stating that 
'All citizens can play a role in building societal resilience against the misuse of digital technology. We all need to deepen our understanding of the political, social, cultural and economic impacts of digital technologies and what it means to use them responsibly. We encourage nations to consider how educational systems can train students to thoughtfully consider the sources and credibility of information.' (United Nations, 2019, p. 26).

Co-operation between the EU and Latin American countries is in line with digital and, more broadly, information technologies. In this regard, both parts of the world are striving to take new steps towards nurturing and further advancing bi-regional cooperation in order to enable digital technology-borne innovations to be an additional driving force in the context of continuous shifting of the limits to human development. Finally, the Fourth Industrial Revolution innovations pave the way for improving educational systems for future generations.

\section{REFERENCES}

Acemoglu, D. \& Robinson, J.A. (2006). What Do We Know about Democracy?, in: Economic Origins of Dictatorship and Democracy (pp. 4887). Cambridge, Cambridge University Press.

Brzezinski, Z. (1997). Hegemony of a New Type, in: The Grand Chessboard: American Primacy and Its Geostrategic Imperatives (pp. 3-29). New York, Basic Books.

Corrado, C., Haskel, J., Jona-Lasinio, C\&Iommi, M. (2016). [Introduction]. In:European Investment Bank (EIB), Intangible investment in the EU and US before and since the Great Recession and its contribution to productivity growth (pp. 2-3). EIB Working Papers 2016/08, Luxembourg.

De Soto, H. (2000). By Way of Conclusion, in: The Mystery of Capital: Why Capitalism Triumphs in the West and Fails Everywhere Else (pp. 169-184). New York, Basic Books.

Dujić, I. (2007). Odnosi između Evropske unije i Srednje Amerike, Evropsko zakonodavstvo, VI (19-22), pp. 87-91.

Dujić, I. (2016). Bolivia and Paraguay: The Integration of South American Countries as an Obstacle to Conflict, The Review of International Affairs, LXVII (1162-1163), pp. 40-56.

EU-LAC Foundation, CERALE \& Institut des Amériques. (2017). Latin American SMEs and the European market, in: The Internationalisation of 
Latin American SMEs and their Projection in Europe (pp. 41-52). Hamburg, The EU-LAC Foundation. Retireved from DOI: 10.12858/0317EN.

European Parliament, Directorate-General for External Policies of the Union. (2020). The EU and Latin America: towards a stronger partnership? Retrieved from DOI: $10.2861 / 43647$.

European Parliament, Directorate-General for External Policies of the Union. (2012). The development policy of the European Union in the context of bi-regional relations, in: A new European Union development co-operation policy with Latin America (pp. 25-50). Study of the European Parliament. Published by the European Union.

European Sources Online (ESO). (2016). Information Guide: EU-Latin America Relations. Cardiff, Cardiff University Press.

Feenstra, R.C. (1998). Integration of Trade and Disintegration of Production in the Global Economy, The Journal of Economic Perspectives, 12(4), pp. 31-50.

Flecker, J. (2018). Austria: Challenging the perception of technology as an end in itself, in: J. O'Reilly, F. Ranft \& M. Neufeind (Eds.), Work in the Digital Age: Challenges of the Fourth Industrial Revolution (pp. 357-370). London, Rowman \& Littlefield International Ltd.

Freres, C. (2000). The European Union as a Global "Civilian Power": Development Cooperation in EU-Latin American Relations, Journal of Interamerican Studies and World Affairs, 42(2), pp. 63-85.

Gardini, G.L. \& Ayuso, A. (2015). EU-Latin America and Caribbean Interregional relations: complexity and change. The ATLANTIC FUTURE seminar in Lisbon.

European Parliamentary Research Service (EPRS). (2019). EU trade with Latin America and the Caribbean: Overview and figures. Brussels, European Union, retrieved from https://www.europarl.europa.eu/RegData/ etudes/IDAN/2019/644219/EPRS_IDA(2019)644219_EN.pdf.

Haskel, J. \& Westlake, S. (2018). Capitalism without Capital: The Rise of the Intangible Economy. Princeton, Princeton University Press.

Hernández, R. (2015). The Collapse of Socialism Is beyond the Present Horizon, in: P. Brenner, M. R. Jiménez, J. M. Kirk \& W. M. LeoGrande (Eds.), A Contemporary Cuba Reader: The Revolution under Raúl Castro (pp. 162-171). New York, Rowman \& Littlefield Publishers.

Kindleberger, C.P. (1996). Germany, the Latecomer, in: World Economic Primacy: 1500-1990 (pp. 149-171). New York, Oxford University Press. 
Kruijt, D. (2001). Low Intensity Democracies: Latin America in the PostDictatorial Era, Bulletin of Latin American Research, 20(4), pp. 409-430.

Magstadt, T.M. (2013). Political Leadership: The Many Faces of Power, in: Understanding Politics: Ideas, Institutions, and Issues (pp. 305-332). Belmont, CA, Cengage Learning.

Mainwaring, S. (2006). The Crisis of Representation in the Andes. Journal of Democracy, 17(3), pp. 13-27. Retrieved from DOI: 10.1353/jod.2006.0048.

Malamud, A. (2010). Latin American Regionalism and EU Studies, Journal of European Integration, 32(6), pp. 637-657. Retrieved from DOI: 10.1080/07036337.2010.518720.

McNair, B. (1999). Party political communication I: Advertising, in: J. Curran (Ed.), An Introduction to Political Communication (pp. 93-124). London, Routledge.

Molinas, C. and de la Escosura, L.P. (1989). Was Spain Different?: Spanish Historical Backwardness Revisited, Explorations in Economic History 26(4), pp. 385-402.

O'Reilly, J., Ranft, F. \& Neufeind, M. (2018). [Introduction], in: J. O'Reilly, F. Ranft \& M. Neufeind (Eds.), Work in the Digital Age: Challenges of the Fourth Industrial Revolution (pp. 1-24). London, Rowman \& Littlefield International Ltd.

OECD. (2007). The emergence of Latin Multinationals, retrieved from http:// www.oecd.org/dev/40512615.pdf.

Panizza, F. (2009). Contemporary Latin America development and democracy beyond the Washington consensus. London \& New York, Zed books.

Schejtman, A. (2004). Trade and Development: the Links between Latin America and the European Union, in: M.V. León (Ed.), Development Cooperation between the European Union and Latin America: Evaluation and Prospects (pp. 65-90). Santiago, RIMISP and ICCO.

Smith, B.C. (2003). Neo-colonialism and Dependency, in: Understanding Third World Politics: Theories of Political Change and Development (pp. 75107). Basingstoke, Hampshire, Palgrave Macmillan.

The Economic Commission for Latin America and the Caribbean (ECLAC). (2018). The keys to more inclusive production development: the role of knowledge and digitalization, in: The European Union and Latin America and the Caribbean: Convergent and sustainable strategies in the current global environment (pp. 57-78). Santiago, United Nations. 
Union of South American Nations (UNASUR). (2008). South American Union of Nations Constitutive Treaty.

United Nations. (2015). Goal 7: Ensure Environmental sustainability, in: C. Way (Ed.), The Millennium Development Goals Report 2015 (pp. 52-61). New York, United Nations.

United Nations. (2019). The Age of Digital Interdependence. Report of the UN Secretary-General's High-level Panel on Digital Cooperation. New York, United Nations.

Wilkinson, B.W. (1993). Trade Liberalization, the Market Ideology, and Morality: Have We a Sustainable System?, in: R. Grinspun \& M. A. Cameron (Eds.), The Political Economy of North American Free Trade (pp. 27-44). London, Macmillan Press Ltd.

Wood, E. M. (2005). The Detachment of Economic Power, in: Empire of Capital (pp. 9-25), New York, Verso.

World Bank Group and the United Nations Development Programme. (2016, November 10). Accelerating Universal Access to Education, in: New Report 'Transitioning from the MDGs to the SDGs' (pp. 68-77). Washington, DC, International Bank for Reconstruction and Development/ The World Bank and New York, United Nations Development Programme.

World Trade Organization (WTO). (2020). International cooperation on innovation policies in the digital age, in: The World Trade Report 2020: Government policies to promote innovation in the digital age (pp.128-175). Geneva, WTO Secretariat. 